\title{
Evidence of Atlantic Extension in South-East Togo: Case of Fracturing in the Sandstone Relics of Tohoun
}

\author{
Essodina Padaro, Mahaman Sani Tairou*, Yawoa Dzidzo Da Costa, Zikpi Yawovi Amoudji \\ Département de Géologie, Faculté des Sciences, Université de Lomé, Lomé, Togo \\ Email: *msanitairou@yahoo.fr
}

How to cite this paper: Padaro, E., Tairou, M.S., Costa, Y.D.D. and Amoudji, Z.Y. (2021) Evidence of Atlantic Extension in South-East Togo: Case of Fracturing in the Sandstone Relics of Tohoun. International Journal of Geosciences, 12, 517-530. https://doi.org/10.4236/ijg.2021.125028

Received: March 31, 2021

Accepted: May 25, 2021

Published: May 28, 2021

Copyright (c) 2021 by author(s) and Scientific Research Publishing Inc. This work is licensed under the Creative Commons Attribution International License (CC BY 4.0). http://creativecommons.org/licenses/by/4.0/

\begin{abstract}
The sandstone relics of probable Cretaceous age found around Tohoun show an extensional tectonics imprint associated with the Atlantic opening. This imprint consists of normal fault networks well expressed on two sites of outcrop and corresponds to three fracturing episodes materialized by families of conjugated planes striking E-W, NW-SE, and NE-SW. Striated plane data analysis shows three extensional axes successively N-S, NE-SW and NNW-SSE. The reconstructed paleostress tensors can be attributed to pre- to syn-rift phases responsible for the development of primary basin structures in the Gulf of Guinea. This preliminary analysis, concerning only fractures in the basal sequence relics, remains to be extended to the entire Togolese coastal basin to a better definition of the Atlantic dynamic.
\end{abstract}

\section{Keywords}

Fractures, Paleostress, Atlantic Extension, South-Togo

\section{Introduction}

Highly eroded sandstone formations, which have been previously related to the upper sequences ("Continental Terminal") of the Togo coastal basin, outcrop in the Tohoun-Tado area (South-East Togo). By their isolated position in the Pan-African basement area, these formations appear as relics related to an Atlantic transgression. The works of [1] attribute a hypothetical Cretaceous age to these formations allowing considering them as outliers of transgressive phases that are much older than those that were at the origin of the Neogene "Continental Terminal" deposits.

In the Tohoun sandstones, which should be considered equivalent to those at 
Adakplame in Benin [2], is expressed a dense network of fractures generally represented by "tectoglyphes" (varied marks visible on the slickenside allowing to specify the sense of fault throw) bearing planes indicating normal fault movement [3]. Here we analyzed striated planes in the framework of the search for Atlantic extension markers in the Gulf of Guinea basin. In fact, the Tohoun-Tado sandstone formations constitute evidence of the primary phases of the Togolese coastal sedimentary basin development. As the upper sequences, these formations bear fracture network very probably linked to the Atlantic dynamic. But, up to now, in the Togolese coastal basin, as in the whole Gulf of Guinea basin, fracture networks studies for paleostress determination have never been tackled. Furthermore, extension models have been proposed without stress evidence [4] [5]. That explains the initiative of this fault planes analysis in the Tohoun sandstone relics. These deposits could have recorded the imprints of early tectonic episodes that have oriented the Atlantic extension especially in the Togolese portion of the Gulf of Guinea basin.

\section{Geological Setting}

In the West-African sub-region (Figure 1), geological suites belong to:

- The West-African Craton (WAC), consisting of Archean to Paleoproterozoic assemblages and stabilized since the end of the Eburnean orogeny (2000 \pm $200 \mathrm{Ma} ;[6])$,

- The Neoproterozoic to Paleozoic megasequences of Taoudeni and Volta basins,

- The Pan-African belts ( $600 \pm 50 \mathrm{Ma})$ overlapping the WAC and its cover,

- And the Meso-Cenozoic internal (Iullemmeden basin) or coastal (SenegalMauritania basin, Ivory Coast basin, Gulf of Guinea basin and Benue trough) basins. The coastal basins history is linked to the Atlantic opening.

The geology of the South Togo consists of a meso-cenozoic sedimentary cover relying unconformably on a Pan-African gneisso-migmatitic basement. The sedimentary cover is the Togolese portion of the regional Gulf of Guinea basin (Figure 1).

\subsection{The Pan-African Basement}

The Togolese coastal basin basement corresponds to part of the western domain of the so-called "internal zone" of the Pan-African Dahomeyides belt [7]. It consists of gneisso-migmatitic units associated with rare late Pan-African granitic intrusions [8] [9] [10]. These lithostuctural units containing ortho- or para-derived petrographic rocks are considered to be of Eburnean age (2000 $\pm 200 \mathrm{Ma}$; [6]), remobilized during the Pan-African orogeny (600 $\pm 50 \mathrm{Ma}$; [11] [12]). They represent the frontal part of the Benino-Nigerian Shield that collided with the eastern margin of the WAC during the ultimate stage of the Dahomeyides edification [7]. The fracture network in the gneisso-migmatitic units is attributed to the two last Pan-African deformation phases [13] [14] [15]. These major fractures have probably influenced the coastal basin setting up. 


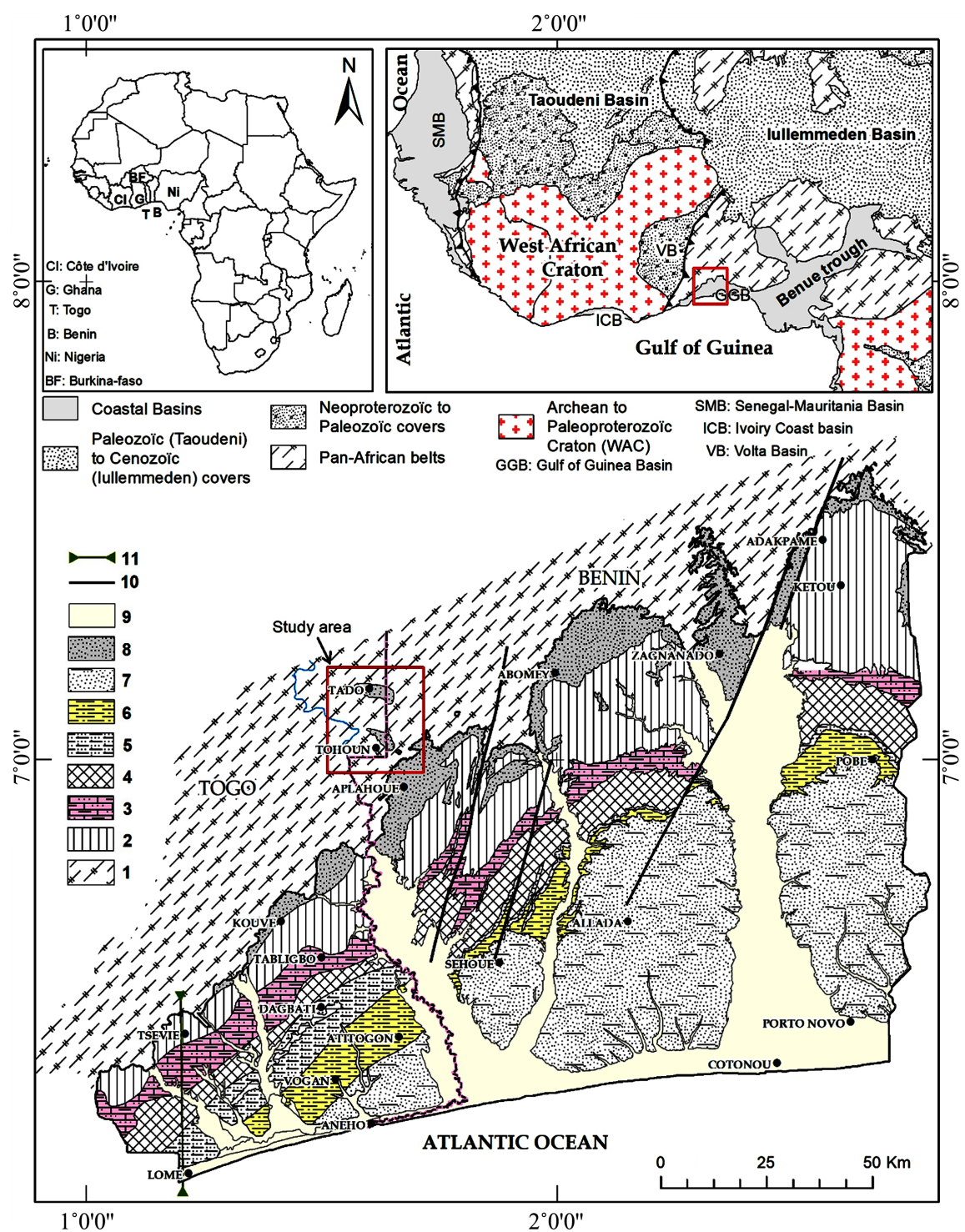

Figure 1. Synthetic map, extracted from the geological maps of Togo [10] and Benin [16], showing the lithological organization of the Benino-Togolese costal basin (Gulf of Benin basin) and location of the Tohoun-Tado sandstone formations. 1 = Pan-African basement; 2 = Maastrichtian deposits; 3 = Paleocene deposits; 4 = Paleocene to lower Eocene deposits; 5 = Lower Eocene deposits; 6 = Middle Eocene deposits; 7 = Oligocene-Miocene deposits; 8 = "Continental terminal" deposits; 9 = fluvio-lacustrine and marine deposits; 10 = Major fractures; 11 = synthetic cross-section location.

\subsection{The Meso-Cenozoic Cover}

The Meso-Cenozoic cover of the Togolese coastal sedimentary basin is defined as a monoclinal mega-sequence with very low dip to the SE where it approaches $600 \mathrm{~m}$ thickness (Figure 2). Both basement and sedimentary cover are compartmentalized by normal faults. Formations outcrop in NE-SW trending parallel bands corresponding to different stages of marine evolution [4]. These outcrops become blurred toward the north of the basin by an erosional limit beyond which occur outliers of the Tohoun-Tado Sandstones (Figure 1). 


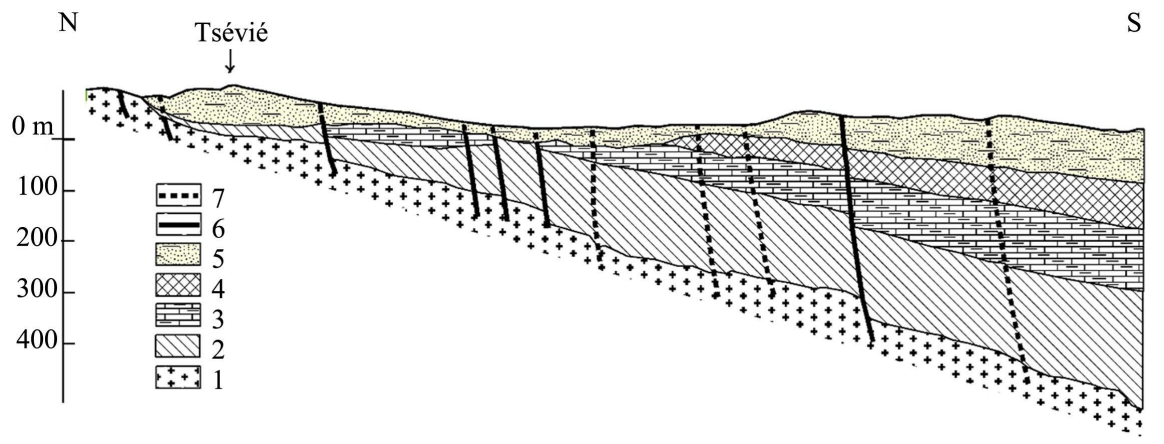

Figure 2. Synthetic cross-section showing the litho-structural organization of the Togolese coastal sedimentary basin in the SW (see Figure 1) according to [17] Project report slightly modified. 1 = Pan-African basement; 2 = Cretaceous deposits; 3 = Paleocene deposits; 4 = Eocene deposits; 5 = "Continental terminal" deposits; $6=$ Fault plane; $7=$ supposed fault plane.

According to [4] and [18], the mega-sequence of the Togolese coastal basin consists of three series, namely:

1) The lower series or "Tabligbo Group", consisting, from base to top, of Campanian-Maastrichtian detrital deposits (sands and sandstones), PaleoceneEocene limestones and laminated mudstones;

2) The middle series of lower to middle Eocene age, called the "HahotoeKpogame phosphatic Complex" [4], bringing together, from bottom to top, phosphatic marls, phospharenites (phosphate deposits in exploitation) and phosphatic mudstones;

3) The upper series (upper Eocene to Quaternary) representing the "Continental terminal s.l." and consisting of sandy clay detrital deposits with pebbly horizons. The latter, is separated from the preceding series by an erosion surface (Figure 2).

The genesis and evolution of the Togolese coastal basin, like its West African equivalents, are associated with the process of the opening of the South Atlantic equatorial segment. This opening occurred in the global dynamic of the dislocation of Gondwana that separated the African and South American continents since the Lower Cretaceous [19]-[29]. For [30], these basins have several tectono-sedimentary similarities. They are made of continental (fluvio-lacustrine) pre- to syn-rift valley filling deposits overlain by marine sediments generally transgressive on anterior deposits. Basin filling generally ends with a detrital continental series.

\section{Main Lithological Characteristics of Tohoun Sandstones}

The Tohoun-Tado sandstones occupy the summits of two elliptical interfluves oriented WNW-ESE over a length of 6 to $8 \mathrm{~km}$ (Figure 3). These transboundary outcrops are encountered several kilometers from the northern limit of the coastal basin. Similar relics have been mapped in Benin [2] [16]. In Togo, the Tohoun-Tado Sandstones have been considered as formations of the "Continental terminal" [10] [31]. The works of [1] show that they should rather be 


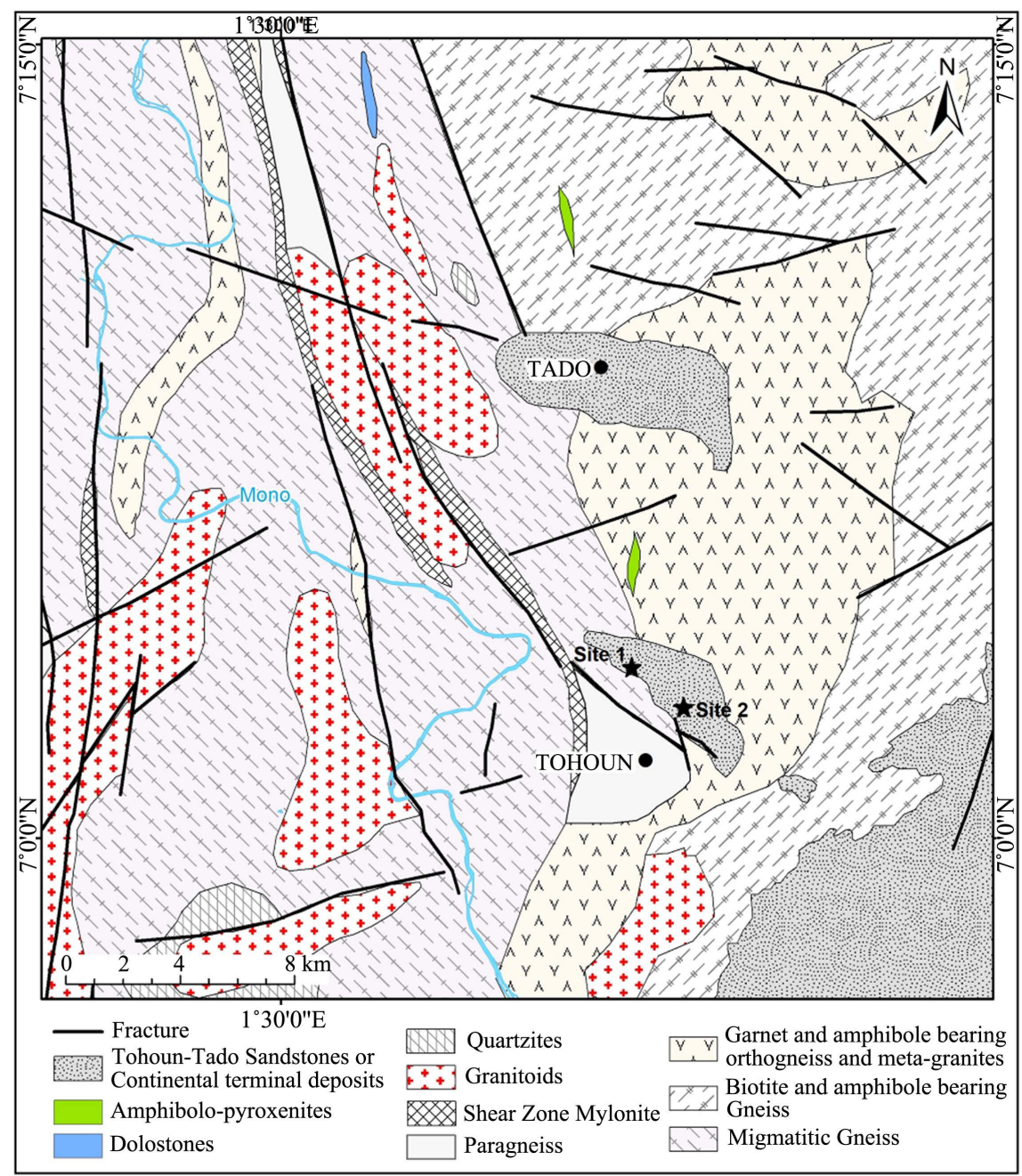

Figure 3. Geological map of the study area showing the lithological components of the Pan-African basement and outcrops of Tohoun-Tado sandstones [10] [16].

attached to the coastal sedimentary basin basal formations. The entire sandy sequence is subdivided into two units separated by an erosional disconformity. The lower unit is called "Tado Sandstones" and the upper unit "Tohoun Sandstones".

In this work the fracture network data has been analyzed. The data was collected from Tohoun outcrops (Figure 3) where the sequence is more complete and the striated planes clearly expressed and well preserved.

On the architectural plan, the Tohoun Sandstone outcrops are tower-like, with a dark color attributed to a carpet covering of lichens (Figure 4(a)). The lithological characteristics are perturbed by intense erosion, ferruginization and dissolution phenomena at the origin of pseudo-karsts.

Strong oblique and cross-bedding stratifications are clearly visible (Figure 4(b)). Fresh rocks are generally massive and characterized by an intergrowth of veinlets with whitish and sometimes little carbonated siliceous infill (Figure 4(c)). They are pale yellowish-brown, with a brown patina and saccharoidal alteration. 

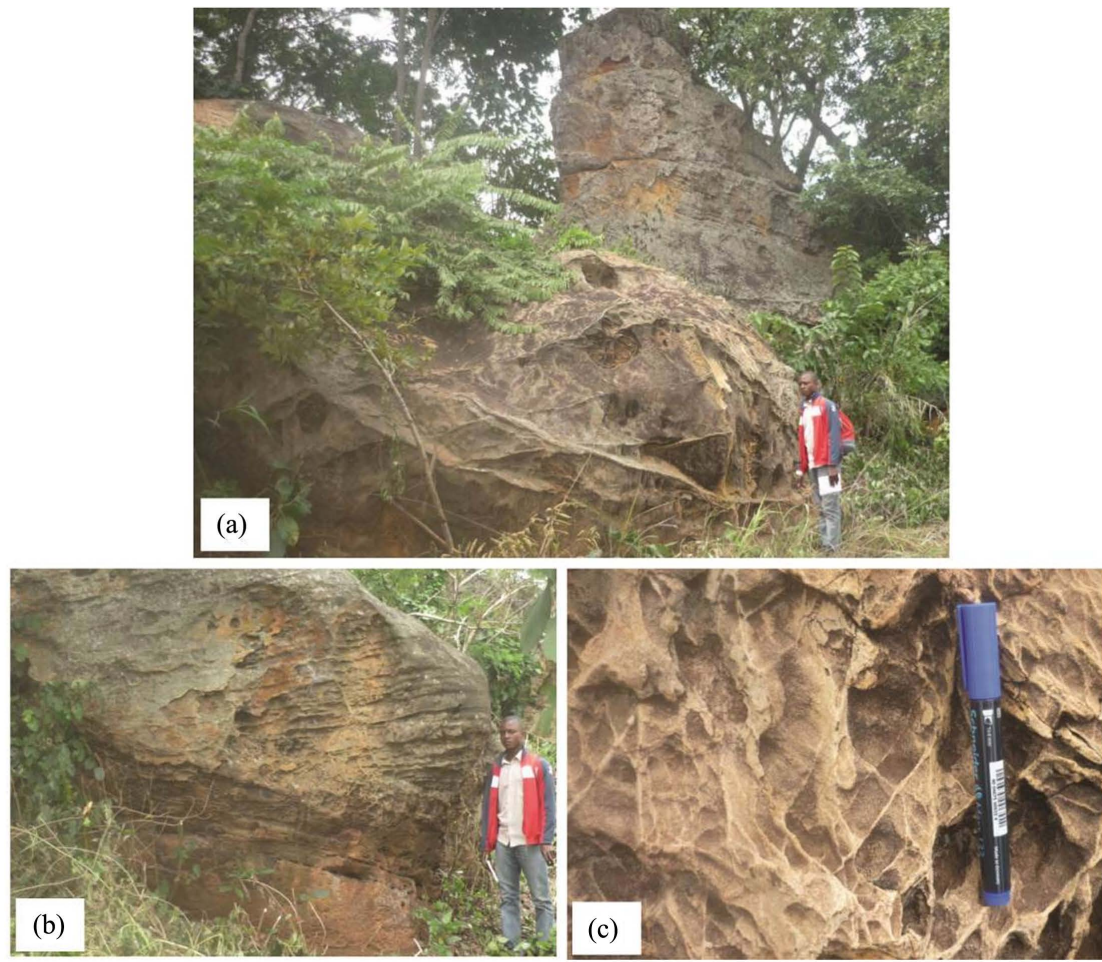

Figure 4. Some characteristic aspects of sandstone outcrops of Tohoun: (a) -Tower-like sandstone outcrops; (b) -Oblique and cross-bedding stratifications; (c) -Highly eroded sandstone outcrop with whitish and siliceous infill veinlets.

The texture is heterogranular, medium to coarse grained or micro-conglomeratic with centimetric quartz pebbles. [1] has described traces of bioturbation in the sandstones.

\section{Analysis of the Fracture Networks}

\subsection{Methodology}

Two faulted sites were studied. The first site (N0703'13.7"; E01 $\left.36^{\prime} 39.6^{\prime \prime}\right)$ includes sandstone outcrops attributed to the lower members of the sequence. The planes surveyed bear striations whose geometry indicates normal fault movements (Figure 5(a)) associating a more or less important strike-slip fault displacement (oblique slip fault, Figure 5(b)), or exclusively strike-slip fault (Figure 5(c)). Outcrops at the second site (N07 $02^{\prime} 12.5^{\prime \prime}$; E01 $\left.37^{\prime} 36.5^{\prime \prime}\right)$ belong to the upper member of the sandstone sequence and only show normal fault type striated planes (Figure 5(d)).

Several plane directions make up the fracture networks at the two sites. Based on the intersection criteria and superposition of incompatible striae [32] [33] [34], the planes are attributed to many fracturing episodes. A total of 334 striated planes were recorded. From this fault population, only 163 planes are retained considering conformity with movement criteria [35]. The measurements were first subjected to manual stereographic processing to complete striae characterization. 

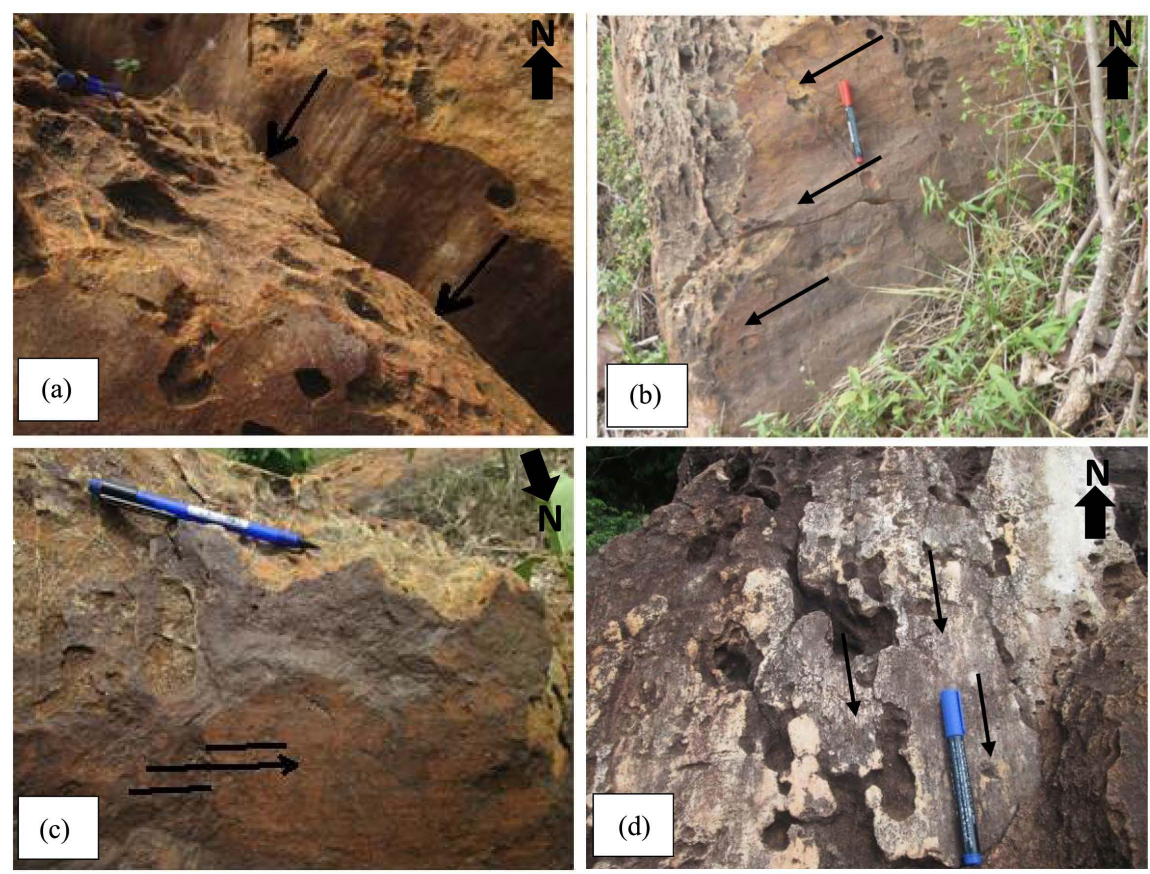

Figure 5. Some striated planes in the Tohoun sandstones. (a) -NW-SE normal fault plane; (b) -NE-SW oblique slip fault plane; and (c) -NW-SE sinistral strike-slip fault plane on site 1 ; (d) -NE-SW normal fault plane on site 2 .

Data on the striated planes were processed using the numerical calculation software Tectonics FP 1.75 [36]. This software requires as inputs, the geometrical parameters of planes (Dip direction/dip) and striae on planes, as well as fault type and the precision for each plane measurement. Three methods are proposed for the calculation of tensors namely: 1) Direct Inversion [37] [38] [39] [40]; 2) Numerical Dynamical Analysis (NDA; [41], review in [42]); and the 3) Dihedra calculation [43] [44] [45]. The Direct Inversion methods are used for inherited faults systems [44] [46], while the NDA allows determining the parameters of deformation axes rather than stressing characteristics. Thus we have chosen the third method (Dihedra calculation) which is recommended for conjugated fault systems [43] [47] [48]. After the treatments, the states of the paleostresses obtained for each system or fracturing episode are synthesized in Table 1.

At site 2, the intersection criteria allowed to establish a relative chronology of at least three episodes of development of striated planes (Figure 6). The first episode is represented by the E-W to WNW-ESE (N80 to N100) planes. The second generation expresses itself in the NW-SE to NNW-SSE (N120 to N160) directions and finally, the last generation corresponds to the NE-SW (N40 to N70) planes. The same generations of normal faults were recorded at site 1, but one notes the presence of families of NE-SW dextral and NW-SE sinistral strike slip faults. Each generation of normal faults is considered as a system allowing determination of the responsible theoretical stress tensor. The system of strike slip faults at the site 1 is considered to be a set of fault reactivation planes linked to the last episode. These planes were analyzed separately. 


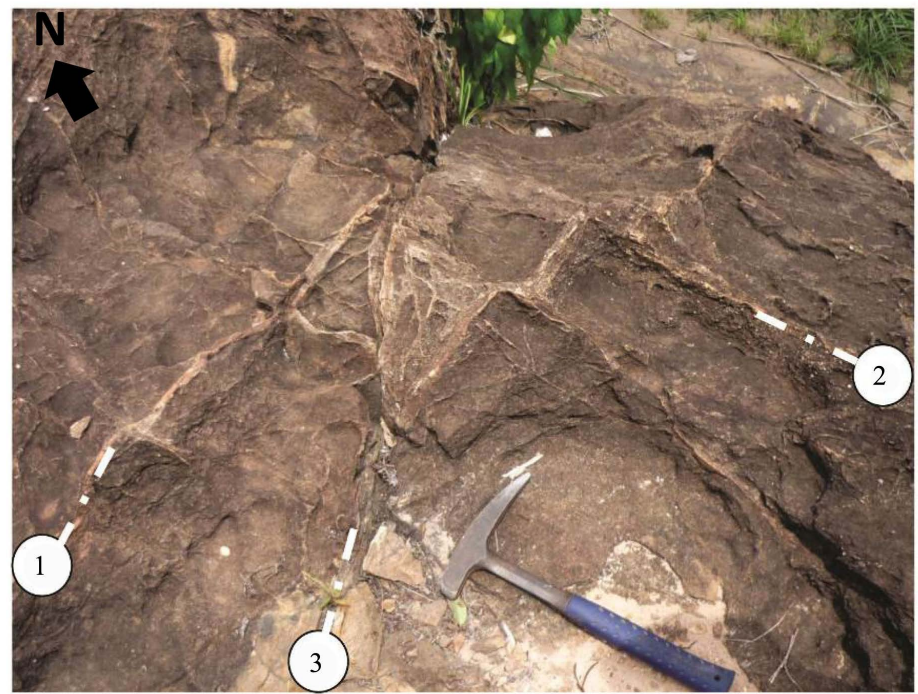

Figure 6. Sandstone outcrop at site 2 showing fracture network corresponding to three episodes of fracturing respectively materialized by E-W (1), N-S to NW-SE (2) and NE-SW (3) plane directions. The planes of precocious generations with siliceous infill are intersected by the last planes. This intersection indicates dextral strike-slip fault displacement which really corresponds to the horizontal lateral throw of normal faulting.

Table 1. Synthesis of striated planes analysis at the two faulted sites of Tohoun sandstones: the table summarizes for each site the geographic coordinates, the type of fault (TF) analyzed (NF = normal fault, $\mathrm{SF}=$ strike-slip fault), the directions of family planes (D), the number of striated planes analyzed $(\mathrm{Nb})$, and the direction and dipping of principal stress axis $(\sigma 1, \sigma 2$ and $\sigma 3)$ obtained.

\begin{tabular}{|c|c|c|c|c|c|c|c|c|}
\hline \multirow{2}{*}{ Site } & \multicolumn{2}{|c|}{ Coordinates } & \multirow{2}{*}{$\mathrm{TF}$} & \multirow{2}{*}{$\mathrm{D}$} & \multirow{2}{*}{$\mathrm{Nb}$} & \multirow{2}{*}{$\sigma 1$} & \multirow{2}{*}{$\sigma 2$} & \multirow{2}{*}{$\sigma 3$} \\
\hline & Longitude & Latitude & & & & & & \\
\hline \multirow{4}{*}{1} & \multirow{4}{*}{ E01 $36^{\prime} 39.6^{\prime \prime}$} & \multirow{4}{*}{ N07 $03^{\prime} 13.7^{\prime \prime}$} & $\mathrm{NF}$ & NW-SE & 24 & $171-86$ & $314-03$ & 044-02 \\
\hline & & & $\mathrm{NF}$ & NE-SW & 09 & $253-64$ & $075-26$ & $344-00$ \\
\hline & & & $\mathrm{NF}$ & $\mathrm{E}-\mathrm{W}$ & 12 & $036-85$ & $268-03$ & $177-04$ \\
\hline & & & SF & NE-SW + NW-SE & 13 & 087-06 & $315-81$ & $178-07$ \\
\hline \multirow{3}{*}{2} & \multirow{3}{*}{$\mathrm{E} 01^{\circ} 37^{\prime} 36.5^{\prime \prime}$} & \multirow{3}{*}{ N07 $02^{\prime} 12.5^{\prime \prime}$} & NF & NW-SE & 18 & $079-76$ & $301-11$ & $209-09$ \\
\hline & & & $\mathrm{NF}$ & NE-SW & 44 & $277-85$ & 063-04 & $153-03$ \\
\hline & & & NF & E-W & 19 & $319-85$ & 098-04 & $188-04$ \\
\hline
\end{tabular}

\subsection{Results}

\section{Site 1}

The striated planes recorded at the site 1 have medium to high dips $\left(40^{\circ}\right.$ to $80^{\circ}$ ) in many directions. The pitch of striae and associated tectoglyphes allow identifying normal, normal strike-slip and strike-slip faults. The network is made up of three major normal fault directions which correspond to three conjugated fault systems associated with different fracturing episodes. The NW-SE planes are more represented than the NE-SW and E-W normal faults. The stress tensors determined for each system are the following: 
- The system of E-W conjugated normal faults express a subvertical maximum principal stress axis $\sigma 1$, oriented N036-85 and a minor stress $\sigma 3$ oriented N177-04 (Figure 7(a));

- The second generation system of NW-SE conjugated normal faults corresponds to a paleostress tensor with principal axes $\sigma 1 \mathrm{~N} 171-86$ and $\sigma 3$ N044-02 (Figure 7(b));

- All the NE-SW normal faults assume a tensor with paleostresses $\sigma 1 \mathrm{~N} 253-64$ and $\sigma 3$ N344-00 (Figure 7(c)).

The strike-slip faults are organized in a system of conjugated families with NE-SW (N40 to N70) dextral and NW-SE (N115 to N130) sinistral planes. This system of strike-slip faults seems to correspond to a tensor of paleostresses, with subhorizontal $\sigma 1$ and $\sigma 3$ oriented N087-06 and N178-07 respectively (Figure $7(d))$.

\section{Site 2}

Sandstones belonging to the upper member of the sequence ("Tohoun Sandstones") bear decimetric to decametric normal fault planes in E-W, NW-SE and NE-SW directions. Thus, in the image of site 1, site 2 shows imprints of the three fracturing episodes. Stress tensor is also determined for each episode.

The primary episode is expressed by the E-W planes generally filled in by a greyish brown to blackish fine grained ferruginous sandstone. Analysis of the system of normal faults indicates a tensor of paleostresses with subvertical $\sigma 1$ N319-85 and $\sigma 3$ N188-04 (Figure 7(e)).
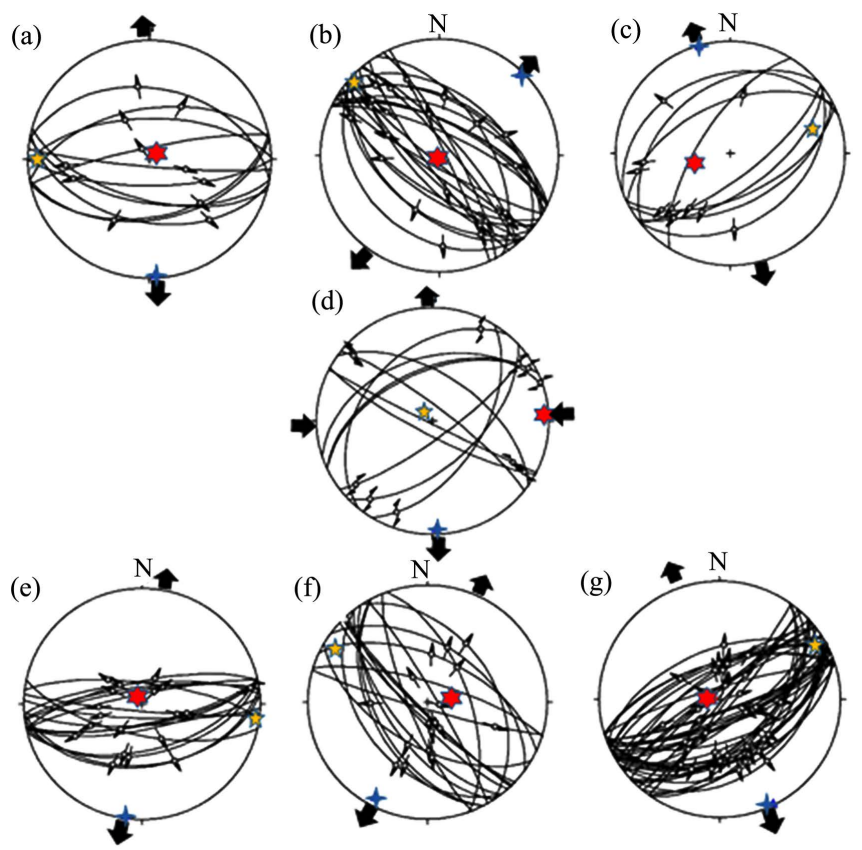

Figure 7. Stereograms (lower hemisphere projection) resulting from striated plane analysis using Tectonics FP 1.75 software [36]. The three extension episodes in the Tohoun sandstones correspond successively to the paleostress axes constructed in stereogram (a), (b), (c), (d) at site 1, and (e), (f), (g) at site 2. The principal stress axes are $\sigma$ l (red stars with 6 branches), $\sigma 2$ (yellow stars with 5 branches) and $\sigma 3$ (blue stars with 4 branches). 
The second episode corresponding to several NE-SW striking planes filled with whitish silica, results from a tensor with $\sigma 1$ N079-76 and $\sigma 3$ N209-09 (Figure 7(f)).

The last concretization of fault tectonics is defined by a population of planes with NE-SW directions. These planes suggest the principal stress axes $\sigma 1 \mathrm{~N} 277-85$ and $\sigma 3 \mathrm{~N} 153-03$ (Figure $7(\mathrm{~g})$ ).

\section{Synthesis and Discussions}

The fracture network in the sandstone formations around Tohoun contains three distinct conjugated normal fault systems. At both faulted sites studied, these systems are defined in the E-W (N80-N100), NW-SE (N120-N160) and NE-SW (N40-N70) directions and are interpreted as successive fracturing episodes. Analysis of fault families of each system allowed identifying the tensors of paleostresses that guided the network development. Thus, the first episode materialized by the E-W normal faults system corresponds to a N-S ( $\sigma 3 \mathrm{~N} 177$ to N188) extension. The second episode represented by the NW-SE conjugated normal faults symbolizes a NE-SW extension with subhorizontal $\sigma 3 \mathrm{~N} 44$ (site 1) or N209 (site 2). The greatest majority of the NE-SW planes mark the impact of the last fracturing episode in the sandstones. On the two sites, the latter episode results from a NNW-SSE ( $\sigma 3 \mathrm{~N} 153$ and N164) extension. It's to this episode that one can attribute the strike-slip faults present at site 1 and which are interpreted as fault reactivation of previous planes.

In summary, the entire fracture network present in the Tohoun sandstones results from a distentional tectonics that is decomposed into three episodes during which the $\sigma 3$ stress seems to have evolved around the N-S axis. From the first to the third episode, the direction of stretching reconstructs successively N-S NE-SW and NNW-SSE. This extension in three episodes can be associated with the early phases of the Togolese coastal basin or more widely the development of the Gulf of Guinea basin. These are the pre- to syn-rift phases of the genesis of Cretaceous big lakes [22] [24]; phases with a dynamic probably hesitant and not uniform from one sector to the other.

In the context of the Togolese coastal basin, the importance of this distensive tectonics had been underscored since the works of [19]. The basin architecture and its paleogeographic evolution denote the essential role of fracturing [4] [10] [18]. The principal directional network components have been defined, but only [3] gives some indications of distension axes. On a regional scale, the extension axes responsible for the fracture network can be integrated into the system of paleostresses of the first phases of continental separation in the Gulf of Guinea. In the South-East of Ghana for example, [13] recorded a few tectoglyphe bearing post-Pan-African normal faults indicating a SE-NW extension probably associated with the precursor tectonics of Jurassic rifting. In the offshore basin in Ghana, the structure established by [49] and the Aptian pull-apart basin extension model of [5] appear to be in conformity with a NE-SW stretch axis. Also, 
concerning the branch of the Benue graben, [22] has identified a NE-SW syn-rift stretch axis.

In the case, these preliminary results of microtectonics analysis of the Atlantic opening and extension markers in the Tohoun sandstone relics are a first. Thus, for a better interpretation of the reconstructed paleostress axes, a study of the fracture network at the scale of the entire Togolese coastal basin would be necessary.

\section{Conflicts of Interest}

The authors declare no conflicts of interest regarding the publication of this paper.

\section{References}

[1] Amoudji, Y.Z. (2017) Caractérisation des dépôts gréseux de Tohoun et de Tado. Master Dissertation, No. 80, Université de Lomé, Lomé.

[2] Affaton, P., Houessou, A. and Gomez, G. (1985) La formation d'Adakplame (Bénin, Ouest-Afrique) n'appartient pas au Continental Terminal. Journal of African Earth Sciences, 3, 359-364. https://doi.org/10.1016/0899-5362(85)90009-0

[3] Akakpo, O.S. (2017) Etude comparée de la fracturation Socle et couverture dans le sud-Togo. Master Dissertation, No. 87, Université de Lomé, Lomé.

[4] Johnson, A.K.C. (1987) le bassin côtier à phosphates du Togo (Maastrichtien-Eocène moyen). Ph.D. Dissertation, Université de Bourgogne, Université de Lomé, Lomé.

[5] Antobreh, A.A., Faleide, J.I., Tsikalas, F. and Planke, S. (2009) Rift-Shear Architecture and Tectonic Development of the Ghana Margin Deduced from Multichannel Seismic Reflection and Potential Field Data. Marine and Petroleum Geology, 26, 345-368. https://doi.org/10.1016/j.marpetgeo.2008.04.005

[6] Rocci, G., Bronner, G. and Deschamps, M. (1991) Crystalline Basement of the West African Craton. In: Dallmeyer, R.D. and Lécorché, J.P., Éds., The West African Orogens and Circum-Atlantic Correlatives, Springer, Berlin, Heidelberg, 31-61. https://doi.org/10.1007/978-3-642-84153-8_3

[7] Affaton, P., Rahaman, M.A., Trompette, R. and Sougy, J. (1991) The Dahomeyide Orogen: Tectonothermal Evolution and Relationships with the Volta Basin. In: Dallmeyer, R.D. and Lécorché, J.P., Éds., The West African Orogens and CircumAtlantic Correlatives, Springer, Berlin, Heidelberg, 107-122. https://doi.org/10.1007/978-3-642-84153-8_6

[8] Alayi, G. (2018) Les granitoïdes tardifs de la chaîne panafricaine des Dahomeyides au Togo: Etude pétro-structurale, structurale et géochronologie. Pétrologie-Géochimie, Ph.D. Dissertation, No. 646, Université de Lomé, Lomé.

[9] Padaro, E. (2017) Caractérisation pétro-structurale du complexe migmatitique de la zone interne des Dahomeyides au Sud-Togo. Master Dissertation, No. 89, Université de Lomé, Lomé.

[10] Sylvain, J.-P., Aregba, A., Assih-Edeou, P., Castaing, C., Chevremont, P.H., Collart, J., Monciardini, C., Marteau, P., Ouassane, I. and Tchota, K. (1986) Notice explicative de la carte géologique au 1/200000 du Togo. Feuilles Lomé et Atakpamé, Lomé.

[11] Affaton, P., Kröner, A. and Seddoh, K.F. (2000) Pan-African Granulites Formation in the Kabye Massif of Northern Togo (West Africa): $\mathrm{Pb}-\mathrm{Pb}$ Zircon Ages. International Journal of Earth Sciences, 88, 778-790. 
https://doi.org/10.1007/s005310050305

[12] Kalsbeek, F., Affaton, P., Ekwueme, B., Frei, R. and Thrane, K. (2012) Geochronology of Granitoid and Metasedimentary Rocks from Togo and Benin, West Africa: Comparisons with NE Brazil. Precambrian Research, 196-197, 218-233. https://doi.org/10.1016/j.precamres.2011.12.006

[13] Tairou, M.S., Affaton, P., Anum, S. and Fleury, T.J. (2012) Pan-African Paleostresses and Reactivation of the Eburnean Basement Complex in Southeast Ghana (West Africa). Journal of Geological Research, 2012, Article ID: 938927, 15 p. https://doi.org/10.1155/2012/938927

[14] Tairou, M.S., Affaton, P., Gélard, J.-P., Aïte, R. and Sabi, B.E. (2007) Panafrican Brittle Deformation and Palaeostress Superposition in the Northern Togo (West Africa). Comptes Rendus Geoscience, 339, 849-857.

https://doi.org/10.1016/j.crte.2007.08.001

[15] Chala, D., Tairou, M.S., Wenmenga, U., Kwekam, M., Affaton, P., Kalsbeek, F., Tossa, C. and Houéto, A. (2015) Pan-African Deformation Markers in the Migmatitic Complexes of Parakou-Niki (Northeast Benin). Journal of African Earth Sciences, 111, 387-398. https://doi.org/10.1016/j.jafrearsci.2015.08.009

[16] Institutional Review Board (1989) Notice explicative de la carte géologique à 1/200 000. Feuilles Pira-Savé, Abomey-Zagnanado, Lokossa-Porto-Novo. Institutional Review Board, Bénin.

[17] Programa de las Naciones Unidas para el Desarrollo (1982) Atlas des ressources et besoins en eau. Projet TOG/75/008 "Stratégie d'amenagement des eaux. Laboratoire Central d'Hydraulique de France, TOGO, TOG/75/008, Programa de las Naciones Unidas para el Desarrollo, New York.

[18] Da Costa, Y.D.P. (2005) Biostratigraphie et paléogéographie du bassin côtier du Togo. Géologie sédimentaire, Ph.D. Dissertation, Université de Lomé, Togo.

[19] Slansky, M. (1962) Contribution à l'étude géologique du Bassin sédimentaire cotier du Dahomey et du togo. Mémoire 11, Bureau de Recherches Géologiques et Minières, Orléans.

[20] De Klasz, I. and Jan Du Chene, R. (1978) Presence of Albian-Cenomanian in South-Western Nigeria and Its Paleogeographic Implications. In: Compte Rendu de la Société de Physique et d Histoire Naturelle de Genève, N.S., 13, 10-15.

[21] Mascle, J. and Blarez, E. (1987) Evidence for Transform Margin Evolution from the Ivoiry Coast-Ghana Continental Margin. Nature, 326, 378-381.

https://doi.org/10.1038/326378a0

[22] Popoff, M. (1988) Du Gondwana l'Atlantique sud: Les connexions du foss de la B nou avec les bassins du Nord-Est br silien j usqu' l'ouverture du goife de Guin e au Cr tac inf rieur. Journal of African Earth Sciences, 7, 409-431. https://doi.org/10.1016/0899-5362(88)90086-3

[23] Blarez, E. and Mascle, J. (1988) Shallow Structures and Evolution of the Ivory Coast and Ghana Transform Margin. Marine and Petroleum Geology, 5, 54-64. https://doi.org/10.1016/0264-8172(88)90039-6

[24] Mascle, J., Blarez, E. and Marinho, M. (1988) The Shallow Structures of the Guinea and Ivory Coast-Ghana Transform Margins: Their Bearing on the Equatorial Atlantic Mesozoic Evolution. Tectonophysics, 155, 193-209. https://doi.org/10.1016/0040-1951(88)90266-1

[25] Billman, H.G. (1992) Offshore Stratigrphy and Paleontology of the Dahmez Embayement, West Africa. Nigerian. Association Petroleum Explorationists, 7, 121-130. 
[26] Kjemperud, A., Agbesinyale, W., Agdestein, T., Gustafsson, C. and Yukler, A. (1992) Tectono-Stratigraphic History of the Keta Basin, Ghana with Emphasis on Late Erosional Episodes. Géologie Africaine: Colloque Géologique de Libreville, Recueil des Communications, Libreville, 6-8 May 1991, 55-69.

[27] Helm, C. (2009) Quantification des flux sédimentaires anciens à l'échelle d'un continent : Le cas de l'Afrique au Méso-Cénozoïque. Géologie Appliquée, Université de Rennes 1, Rennes.

[28] Fadiya, S. and Ojoawo, E.A. (2015) Foraminiferal Biostratigraphy and Paleoenvironmental Analyses of Sediments from Folu-1 Borehole. Ibeju-Lekki, Lagos State. Ife Journal of Science, 17, 477-492.

[29] d'Almeida, G.A.F., Kaki, C. and Adejimi, A.J. (2016) Benin and Western Nigeria Offshore Basins: A Stratigraphic Nomenclature Comparison. International Journal of Geosciences, 7, 177-188. http://doi.org/10.4236/ijg.2016.72014

[30] Benkhelil, J., Mascle, J. and Guiraud, M. (Éds.) (1998)Sedimentary and Structural Characteristics of the Cretaceous along the Côte d'Ivoire-Ghana Transform Margin and in the Benue Trough: A Comparison. Proceedings of the Ocean Drilling Program, 159 Scientific Results, 159, 93-99.

https://doi.org/10.2973/odp.proc.sr.159.007.1998

[31] Tchota, K. and Balogan, Y.A. (1985) Rapport de tournée géologique effectuée dans la sous-préfecture du moyen Mono (Tohoun). Bibliothèque Nationale du Royaume du Maroc, Tohoun-Togo, Rapport Inédit.

[32] Bergerat, F. (1985) Déformations cassantes et champs de contrainte tertiaires dans la plate-forme européenne. Thèse de Doctorat d'Etat ès Sciences Naturelles, Université Pierre et Marie Curie Paris 6, Paris.

[33] Bott, M.H.P. (1959) The Mechanics of Oblique Slip Faulting. Geological Magazine, 96, 109-117. https://doi.org/10.1017/S0016756800059987

[34] Etchecopar, A. and Mattauer, M. (1988) Méthodes dynamiques d'analyse des populations de failles. Bulletin de la Societe Geologique de France, 9, 289-302.

https://doi.org/10.2113/gssgfbull.IV.2.289

[35] Petit, J.P. (1987) Criteria for the Sense of Movement on Fault Surfaces in Brittle Rocks. Journal of Structural Geology, 9, 597-608. https://doi.org/10.1016/0191-8141(87)90145-3

[36] Reiter, F. and Acs, P. (2011) TectonicsFP 1.75, Computer Software for Structural Geology. Kargl Computer \& Consulting, Austria.

[37] Angelier, J. and Goguel, J. (1979) Sur une méthode simple de détermination des axes principaux des contraintes pour une population de failles. Comptes rendus de P Académie des Sciences, 282, 307-310.

[38] Etchecopar, A., Vasseur, G. and Daignieres, M. (1981) An Inverse Problem in Microtectonies for the Determination of Stress Tensors from Fault Striation Analysis. Journal of Structural Geology, 3, 51-65. https://doi.org/10.1016/0191-8141(81)90056-0

[39] Sperner, B., Ratschbacher, L. and Ott, R. (1993) Fault-Striae Analysis: A Turbo Pascal Program Package for Graphical Presentation and Reduced Stress Tensor Calculation. Computers \& Geosciences, 19, 1361-1388. https://doi.org/10.1016/0098-3004(93)90035-4

[40] Dutta, D., Biswas, T. and Mukherjee, S. (2019) Arc-Parallel Compression in the NW Himalaya: Evidence from Structural and Palaeostress Studies of Brittle Deformation from the Clasts of the Upper Siwalik, Uttarakhand, India. Journal of Earth System 
Science, 128, Article No. 125. https://doi.org/10.1007/s12040-019-1138-1

[41] Spang, J.H. (1972) Numerical Method for Dynamic Analysis of Calcite Twin Lamellae. Geological Society of America Bulletin, 83, 467-472. https://doi.org/10.1130/0016-7606(1972)83[467:NMFDAO]2.0.CO;2

[42] Shaikh, M.A., Maurya, D.M., Mukherjee, S., Vanik, N.P., Padmalal, A. and Chamyal, L.S. (2020) Tectonic Evolution of the Intra-Uplift Vigodi-Gugriana-Khirasra-Netra Fault System in the Seismically Active Kachchh Rift Basin, India: Implications for the Western Continental Margin of the Indian Plate. Journal of Structural Geology, 140, Article ID: 104124. https://doi.org/10.1016/j.jsg.2020.104124

[43] Angelier, J. and Mechler, P. (1977) Sur une méthode graphique de recherche des contraintes principales également utilisable en tectonique et en séismologie: la méthode des dièdres droits. Bulletin de la Société Géologique de France, 19, 1309-1318. https://doi.org/10.2113/gssgfbull.S7-XIX.6.1309

[44] Angelier, J. (1989) Tectonique cassant et néotectonique. Annales de la Société Géologique de Belgique, 112, 283-307.

[45] Vanik, N., Shaikh, M.A., Mukherjee, S., Maurya, D.M. and Chamyal, L.S. (2018) Post-Deccan Trap Stress Reorientation under Transpression: Evidence from Fault Slip Analyses from SW Saurashtra, Western India. Journal of Geodynamics, 121, 9-19. https://doi.org/10.1016/j.jog.2018.06.004

[46] Angelier, J. (1990) Inversion of Field Data in Fault Tectonics to Obtain the Regional Stress-III. A New Rapid Direct Inversion Method by Analytical Means. Geophysical Journal International, 103, 363-376. https://doi.org/10.1111/j.1365-246X.1990.tb01777.x

[47] Angelier, J. (1983) Analyses qualitative et quantitative des populationsde jeux de failles. Bulletin de la Societe Geologique de France, 25, 661-672. https://doi.org/10.2113/gssgfbull.S7-XXV.5.661

[48] Arthaud, F. (1969) Méthode de détermination graphique des directions de raccourcissement, d'allongement et intermédiaire d'une population de failles. Bulletin de la Societe Geologique de France, 11, 729-737. https://doi.org/10.2113/gssgfbull.S7-XI.5.729

[49] Attoh, K. and Brown, L. (2008) Deep Structure of the Southeastern Margin of the West African Craton from Seismic Reflection Data, Offshore Ghana. Geological Society, London, Special Publications, 297, 499-508. https://doi.org/10.1144/SP297.24 